\title{
Snca and Bdnf Gene Expression in the VTA and Raphe Nuclei of Midbrain in Chronically Victorious and Defeated Male Mice
}

\author{
Natalia N. Kudryavtseva ${ }^{1 *}$, Natalia P. Bondar ${ }^{1}$, Ul'yana A. Boyarskikh ${ }^{2}$, Maxim L. Filipenko ${ }^{2}$ \\ 1 Institute of Cytology and Genetics SD RAS, Novosibirsk, Russian Federation, 2 Institute of Chemical Biology and Basic Medicine SD RAS, Novosibirsk, Russian Federation
}

\begin{abstract}
Background: Alpha-synuclein ( $\alpha$-Syn) is a small neuronal protein that has been found to be expressed throughout the brain. It has been shown that $\alpha$-Syn regulates the homeostasis of monoamine neurotransmitters and is involved in various degenerative and affective disorders. There is indication that $\alpha$-Syn may regulate expression of the brain-derived neurotropic factor (BDNF) which plays an important role in the mood disorders.

Methodology/Principal Findings: The study aimed to analyze the mRNA levels of Snca and Bdnf genes in the ventral tegmental area (VTA) and raphe nuclei of the midbrain in male mice that had each won or defeated 20 encounters (20-time winners and 20-time losers, respectively) in daily agonistic interactions. Groups of animals that had the same winning and losing track record followed by a no-fight period for 14 days (no-fighting winners and no-fighting losers) were also studied. Snca mRNA levels were increased in the raphe nuclei in the 20-time losers and in the VTA of the 20-time winners. After nofight period Snca mRNA levels decreased in both groups. Snca mRNA levels were similar to the control level in the VTA of the 20-time losers and in the raphe nuclei of the 20-time winners. However Snca gene expression increased in these areas in the no-fighting winners and no-fighting losers in comparison with respective mRNA levels in animals before no-fight period. $B d n f$ mRNA levels increased in VTA of 20-time winners. Significant positive correlations were found between the mRNA levels of Snca and Bdnf genes in the raphe nuclei.
\end{abstract}

Conclusions/Significance: Social experience affects Snca gene expression depending on brain areas and functional activity of monoaminergic systems in chronically victorious or defeated mice. These findings may be useful for understanding the mechanisms of forming different alpha-synucleinopathies.

Citation: Kudryavtseva NN, Bondar NP, Boyarskikh UA, Filipenko ML (2010) Snca and Bdnf Gene Expression in the VTA and Raphe Nuclei of Midbrain in Chronically Victorious and Defeated Male Mice. PLoS ONE 5(11): e14089. doi:10.1371/journal.pone.0014089

Editor: Mark R. Cookson, National Institutes of Health, United States of America

Received July 21, 2010; Accepted October 21, 2010; Published November 23, 2010

Copyright: (C) 2010 Kudryavtseva et al. This is an open-access article distributed under the terms of the Creative Commons Attribution License, which permits unrestricted use, distribution, and reproduction in any medium, provided the original author and source are credited.

Funding: This work was supported by research grant (22.16) from the Russian Academy of Sciences (Molecular and Cellular Biology Program). The funders had no role in study design, data collection and analysis, decision to publish, or preparation of the manuscript.

Competing Interests: The authors have declared that no competing interests exist.

*E-mail: natnik@bionet.nsc.ru

\section{Introduction}

Alpha-synuclein ( $\alpha$-Syn) is a small neuronal protein localized in the presynaptic compartment of neurons that has been found to be expressed throughout the brain [1,2]. It has been shown that $\alpha$ Syn regulates the homeostasis of monoamine neurotransmitters, through its trafficking, and regulation of the cell surface expression and, thereby, the activity of dopamine, serotonin and norepinephrine transporters [3-5]. $\alpha$-Syn is involved in various degenerative disorders such as Parkinson's disease, dementia with Lewy bodies [review 1, 3, 6, 7], which are recognized as alphasynucleinopathies. It is suggested that $\alpha$-Syn may also play a pathophysiological role in depressive symptoms $[8,9]$.

Previous data have revealed that long positive or negative fighting experience in daily agonistic interactions in male mice is accompanied by different changes in brain neurochemical activities. It has been experimentally demonstrated that repeated aggression which is accompanied by victories, leads to total activation of brain dopaminergic systems. This activation was detected in the winners as elevated DOPAC (3,4-dihydroxyphe- nyleacetic acid) levels or/and increased DOPAC/DA (dopamine) ratios in different brain areas $[10,11]$. Enhanced expression of the Th, Dat1 and Snca genes [12,13], which are associated with brain dopaminergic systems was shown in the ventral tegmental area (VTA) of the winners. Reduced activity of brain serotonergic system was suggested to be developed under repeated experience of aggression as has been shown by decreased tryptophan hydroxylase activity in some brain areas [14-16]. Daily social defeats are accompanied by activation of serotonergic system as shown by changes of serotonin and 5-hydroxyindoleacetic acid levels in different brain areas of the losers [10,17] and enhanced expression of Sert and MaoA genes in the raphe nuclei of the midbrain [18]. Reduced activity of brain dopaminergic systems was supposed in defeated animals [17].

The paper aimed to study the possible changes of Snca gene expression in animals with different brain monoaminergic activity. We focused on the VTA containing the cell bodies of mesolimbic dopaminergic neurons, because mesolimbic dopaminergic projections from the VTA play an important role in the mediation of rewarding processes [19] which is supposed to accompany positive 
fighting experience [20,21]. The raphe nuclei containing the cell bodies of serotonergic neurons whose projections are involved into regulation of stress, depression, anxiety and in many kinds of social behaviors was also studied.

The brain-derived neurotrophic factor (BDNF) is associated with many psychiatric disorders such as depression and anxiety $[22,23]$ by participating in differentiation, growth and maintenance of neuronal cells. Differently directed changes BDNF and $\alpha$ Syn were revealed in the pathogenesis of Parkinson's disease affecting dopaminergic systems [7;24]. Moreover there was indication that overexpression of $\alpha$-syn may decrease BDNF expression [25]. It was supposed that Bdnf gene together with Snca gene in the VTA and raphe nuclei of midbrain may be involved in the consequences of repeated agonistic interactions. Expression of $B d n f$ gene was also studied in the VTA and raphe nuclei of midbrain in the mice before and after period of repeated agonistic interactions.

\section{Materials and Methods}

\section{Animals and housing}

Adult male mice of the C57BL/6J strain from a stock maintained in the Animal Facility of the Institute of Cytology and Genetics, SD RAS, (Novosibirsk, Russia) were used. The animals were housed under standard conditions (12:12 h light/ dark regime, switch-on at 8.00 a.m.; food (pellets) and water available ad libitum). Mice were weaned at one month of age and housed in groups of $8-10$ in plastic cages $(36 \times 23 \times 12 \mathrm{~cm})$. Experiments were performed on mice 10-12 weeks of age.

\section{Ethics Statement}

All procedures were in compliance with the European Communities Council Directive of November 24, 1986 (86/ 609/EEC). This study was approved by Scientific Council N 9 of the Institute of Cytology and Genetics SD RAS of March, 24, 2010, N 613.

\section{Chronic agonistic interactions (winners and losers)}

Aggressive or submissive behaviors in male mice were induced using the sensory contact model [26]. Pairs of weight-matched animals were each placed in a steel cage $(28 \times 14 \times 10 \mathrm{~cm})$ bisected by a perforated transparent partition allowing the animals to see, hear and smell each other, but preventing physical contact. The animals were left undisturbed for three days to adapt to new housing conditions and sensory contact before they were exposed to encounters. In the second half of the light period, the lid was replaced by a transparent one and five minutes later the partition was removed for 10 minutes to encourage agonistic interactions. The superiority of one of the mice was firmly established within two or three encounters (three days) with the same opponent. The superior mouse would be attacking, biting and chasing another, who would be displaying only defensive behavior (sideways postures, upright postures, withdrawal, lying on the back or freezing). As a rule, in our experiments, aggressive confrontations between males are discontinued by lowering the partition if the aggression has lasted more then $3 \mathrm{~min}$ or less. Each defeated mouse (loser) was exposed to the same winner for three days, while afterwards each loser was placed, once a day after the fight, in an unfamiliar cage with an unfamiliar winner behind the partition. Each victorious mouse (winner) remained in its original cage. This procedure was performed for 20 days and yielded an equal number of winners and losers.

Five groups of animals were used. (1) 20-time winners: a group of mice that had each won 20 encounters in succession (2) No- fighting winners: a group of 20-time winners who were allowed to live for 14 days after the last encounter without agonistic interactions; (3) 20--time losers: a group of mice that had each defeated 20 encounters; (4) No-fighting losers: a group of 20-time losers who were allowed to live for 14 days after the last encounter without agonistic interactions. During the no-fight period animals shared a cage with a partner (losers or winners); the partition between their compartments being down at all times, to prevent encounters. (5) Controls: the mice that had been housed individually for five days. The rationale for this choice is that it gives the best trade-off between group housing and social isolation: five days is sufficient for group housing to no longer be a factor and insufficient for social isolation to become a factor. Special investigations confirmed strong rationality of this control in the sensory contact model [27]. Each experimental group contained 7-13 animals.

To measure mRNA levels in the brain areas, all the mice were decapitated simultaneously: 20-time winners and 20-time losers, 24 hours after the last agonistic interaction; no-fighting winners and no-fighting losers, immediately after 14-day no-fight period; and the controls, on day 6 of individual housing. The mouse brains were removed and chilled rapidly on ice. The VTA and raphe nuclei were dissected according to the Mouse Brain Atlas [28]. Obtained tissue was rapidly frozen in liquid nitrogen and stored at $-70^{\circ} \mathrm{C}$ until used.

Total RNA extraction and reverse transcription. Total RNA was extracted from each individual brain tissue sample using the Chomczynski and Sacchi method [29] with modifications. Total RNA was quantified by measuring the absorbance at $260 \mathrm{~nm}$. The integrity of total RNA was assessed by agarose gel electrophoresis. $1 \mu \mathrm{g}$ of total RNA was used for cDNA synthesis by MoMLV reverse transcriptase (Biosan, Novosibirsk, Russia).

\section{Real-time quantitative PCR}

Amplification was performed using an iQ5 iCycler (Bio-Rad, Hercules, CA, USA). Bdnf, $\beta$-actin (Actb), and cyclophilin (Cphn) mRNA levels were quantified by TaqMan real-time PGR. PGR was performed in a total volume of $25 \mu \mathrm{l}$ containing an aliquot of the RT mixture, dNTPs, the appropriate concentrations of sense and anti-sense primers, a TaqMan probe, PGR buffer, and hotstart Taq DNA polymerase (Biosan, Novosibirsk, Russia). Amplification was run for $2 \mathrm{~min}$ at $96^{\circ} \mathrm{C}$, followed by 37 cycles of $15 \mathrm{~s}$ at $96^{\circ} \mathrm{C}, 45 \mathrm{~s}$ at $61^{\circ} \mathrm{C}$. Fluorescence was monitored for $10 \mathrm{~s}$ after the last cycle.

Snca mRNA levels were quantified by Sybr Green I real-time PCR in a total volume of $25 \mu \mathrm{l}$ containing an aliquot of the RT mixture, dNTPs, the appropriate concentrations of the sense and anti-sense primers, Sybr Green I (Invitrogen), PCR buffer, and hot-start Taq DNA polymerase. Amplification was run for $3 \mathrm{~min}$ at $95^{\circ} \mathrm{C}$, followed by 40 cycles of $10 \mathrm{~s}$ at $92^{\circ} \mathrm{C}, 6 \mathrm{~s}$ at $60^{\circ} \mathrm{C}, 6 \mathrm{~s}$ at $72^{\circ} \mathrm{C}$ and $10 \mathrm{~s}$ at $85^{\circ} \mathrm{C}$. Fluorescence was monitored for $10 \mathrm{~s}$ after the last cycle. To check for the presence of non-specific PCR products or primer-dimers, a melting curve analysis was performed after the final PCR cycle.

Amplification efficiencies were calculated a relative standard curve derived from fourfold serial dilutions of pooled cDNA. In all cases, the amplification efficiency was higher than 85\%. Each sample was PCR-amplified twice. RT-PCR results were quantified using the relative standard curve method. The level of expression of each gene was normalized to the mean level of expression of the $A c t b$ and Cphn genes. The oligonucleotide primers and probes were designed using Beacon Designer 5.0 (PREMIER Biosoft International, USA). The PCR primer and probe sequences are shown in Table 1 . 
Table 1. Primers and probe sequences.

\begin{tabular}{|c|c|c|}
\hline \multirow{2}{*}{$\begin{array}{l}\text { Genes } \\
B d n f\end{array}$} & \multicolumn{2}{|c|}{ Primer and probe sequences } \\
\hline & Sense & 5'-ACTATGGTTATTCATACTTCGGTT-3' \\
\hline & anti-sense & 5'-CCATTCACGCTCTCCAGA-3' \\
\hline & Probe & 5'-FAM-CGTCCACGGACAAGGCAACTT-BHQ1-3' \\
\hline \multirow[t]{2}{*}{ Snca } & Sense & 5'-TGACAGCAGTCGCTCAGA-3' \\
\hline & anti-sense & 5'-CATGTCTTCCAGGATTCCTTC-3' \\
\hline \multirow[t]{3}{*}{ Cphn } & Sense & 5'-GAGAACTTCATCCTAAAGCATACAG-3' \\
\hline & anti-sense & 5'-TCACCTTCCCAAAGACCA-3' \\
\hline & Probe & 5'- TAMRA -CGTTGCCATCCAGCCATTCAG-BHQ2-3' \\
\hline \multirow[t]{3}{*}{ Actb } & Sense & 5'- TCTTTGCAGCTCCTTCGTT -3' \\
\hline & anti-sense & 5'-CGATGGAGGGGAATACAG-3' \\
\hline & Probe & 5'- ROX-CACACCCGCCACCAGTTCGC-BHQ2-3' \\
\hline
\end{tabular}

Statistical analysis. The data are reported as mean \pm SEM. Two-way ANOVA of ranked data was used to reveal effect of factors "social status" (20-time winners and 20-time losers) and "no-fight period" and its interactions. Statistical analysis of data was also performed using the Kruskal-Wallis one-way analysis of variance (ANOVA) with factor "groups" in consideration - the control, 20-time winners, 20-time losers, no-fighting winners and no-fighting losers. A post-hoc pair-wise comparison of the groups was made with the Mann-Whitney $U$ test. Correlations were assessed using Spearman's rank correlation coefficient. We searched for correlations between the Bdnf and Snca mRNA levels in each experimental group separately and in combination. The statistical significance was set at $\mathrm{P} \leq 0.05$; the trend level was set at $0.05<\mathrm{P}<0.1$.

\section{Results}

For the Snca mRNA levels, two-way ANOVA for ranked data reports a significant interaction for "social status" and "no-fight period" factors in the raphe nuclei $(\mathrm{F}(1,47)=15.57, p<0.001)$ and in the $\operatorname{VTA}(\mathrm{F}(1,33)=15.87, p<0.001)$. For the $B \operatorname{dnf} f$ mRNA levels no significant interactions were found between social status and no-fight period effects in the raphe nuclei $(\mathrm{F}(1,47)=1.02, \mathrm{NS})$ and in the $\operatorname{VTA}(\mathrm{F}(1,31)=0.44, \mathrm{NS})$.

Kruskal-Wallis analysis revealed a significant influence of the factor "groups" for the Snca mRNA level in the VTA $(\mathrm{H}$ (4, $\mathrm{N}=44)=14.41, p<0.01)$ and in the raphe nuclei $(\mathrm{H}$ (4, $\mathrm{N}=64)=13.69, p<0.01)$ as well as for the $B \operatorname{dnf}$ mRNA level in the raphe nuclei $(\mathrm{H}(4, \mathrm{~N}=64)=10.58, p<0.05)$. There was no significant influence of the factor "groups" on the Bdnf mRNA level in the $\operatorname{VTA}(\mathrm{H}(4, \mathrm{~N}=42)=2.96, \mathrm{NS})$.

Based on the Mann-Whitney $U$ test (Figure 1), in the VTA, the 20-time winners and no-fighting losers had increased Snca mRNA levels as compared to the control $(\mathrm{U}=16 ; p<0.05$ and $\mathrm{U}=7$; $p<0.05$, respectively). Groups of the 20-time winners and 20-time losers as well as groups of the no-fighting winners and no-fighting losers differed significantly $(\mathrm{U}=31 ; p<0.05$ and $\mathrm{U}=8 ; p<0.05$, respectively). No-fighting losers had increased Snca mRNA levels as compared to the 20-time losers before no-fight period $(\mathrm{U}=2$; $p<0.001)$.

In the raphe nuclei, the no-fighting winners had increased Snca mRNA levels as compared to the 20-time winners $(\mathrm{U}=41$; $p<0.05)$. No-fighting losers had decreased Snca mRNA levels as compared to the levels in the 20-time losers $(U=30 ; \mathrm{p}<0.01)$.
There were significant differences in the Snca mRNA levels between the 20-time winners and 20-time losers $(\mathrm{U}=38$; $p<0.05)$ as well as the no-fighting winners and no-fighting losers $(\mathrm{U}=29$; $p<0.01)$. Differences in mRNA levels between the control and nofighting winners and between the control and 20-time losers were not definitely significant, but strongly suggestive $(p=0.086$ and $\mathrm{p}=0.061$, respectively). The 20-time winners had increased $B d n f$ mRNA level as compared to the control $(\mathrm{U}=22 ; p<0.01)$. Other pair comparisons failed to reach significance.

Based on Spearman's rank correlation coefficient, there were significant positive correlations in the raphe nuclei between the mRNA levels of Bdnf and Snca genes in the groups of the 20-time winners and no-fighting winners $(\mathrm{R}=0.643, \quad p<0.05$ and $\mathrm{R}=0.734, \mathrm{p}<0.01$, respectively); in the group of the 20-time losers $(\mathrm{R}=0.560, p<0.05)$; and in all groups in combination using pooled data from all the groups $(\mathrm{R}=0.397, p<0.001)$. There was one significant positive correlation in the VTA between the mRNA levels of Bdnf and Snca genes in the control $(\mathrm{R}=0.893$, $p<0.01)$.

\section{Discussion}

It has been shown that long positive fighting experience in daily agonistic interactions is accompanied by activation of brain dopaminergic systems and reduced serotonergic activity in male mice [16]. Chronic social defeat stress is accompanied by activation of the brain serotonergic system and, presumably, decreased dopaminergic activities [17]. Our neurochemical observations in the aggressive mice (winners) are in agreement with other studies in animals and humans [30-32].

Two-way ANOVA for the Snca mRNA levels in the raphe nuclei and VTA showed significant interaction effects between "social status" and "no-fight period" factors. This means that expression of the Snca gene in brain areas changes differently in animals with positive or negative fighting experience and that the changed monoaminergic activity influences gene expression during no-fight period. Increased mRNA levels of the Snca gene were found in the 20-time winners' VTA and in the 20-time losers' raphe nuclei in comparison with respective level in opposite social group. On the contrary, decreased Snca mRNA level was found in no-fighting winners' VTA and in the no-fighting losers' raphe nuclei in similar comparisons.

Our data suggests that: the changes in Snca gene expression are a consequence of the functional state of the brain dopaminergic and serotonergic systems. Enhanced expression of the Snca gene due to repeated aggression or defeats is associated with activation of the leading monoaminergic systems: mesolimbic dopaminergic system in the VTA of the 20-time winners and serotonergic system in the raphe nuclei of the 20-time losers. After no-fight period increased Snca gene expression in both areas reverts to the control level. On the contrary, when reduced activity of dopaminergic systems in the 20-time losers' VTA or serotonergic system in the 20-time winners' raphe nuclei is suggested, no changes in Snca gene expression were found under repeated agonistic interactions. After no-fight period the Snca mRNA levels are increased in these areas. Since similar changes in Snca gene expression were found in different brain areas, Snca may act as a common regulator of monoaminergic activity as shown earlier [3,4].

Our data provide evidence that the Snca gene may be part of a feedback mechanism in regulation of neurotransmitters' metabolism. It has been shown, that the presynaptic protein $\alpha$-Syn negatively modulates DAT and SERT activity [6,33]. Increase of the Snca mRNA levels may be a response to the increase of Dat1 mRNA level in the winners' VTA and Sert mRNA level in the 

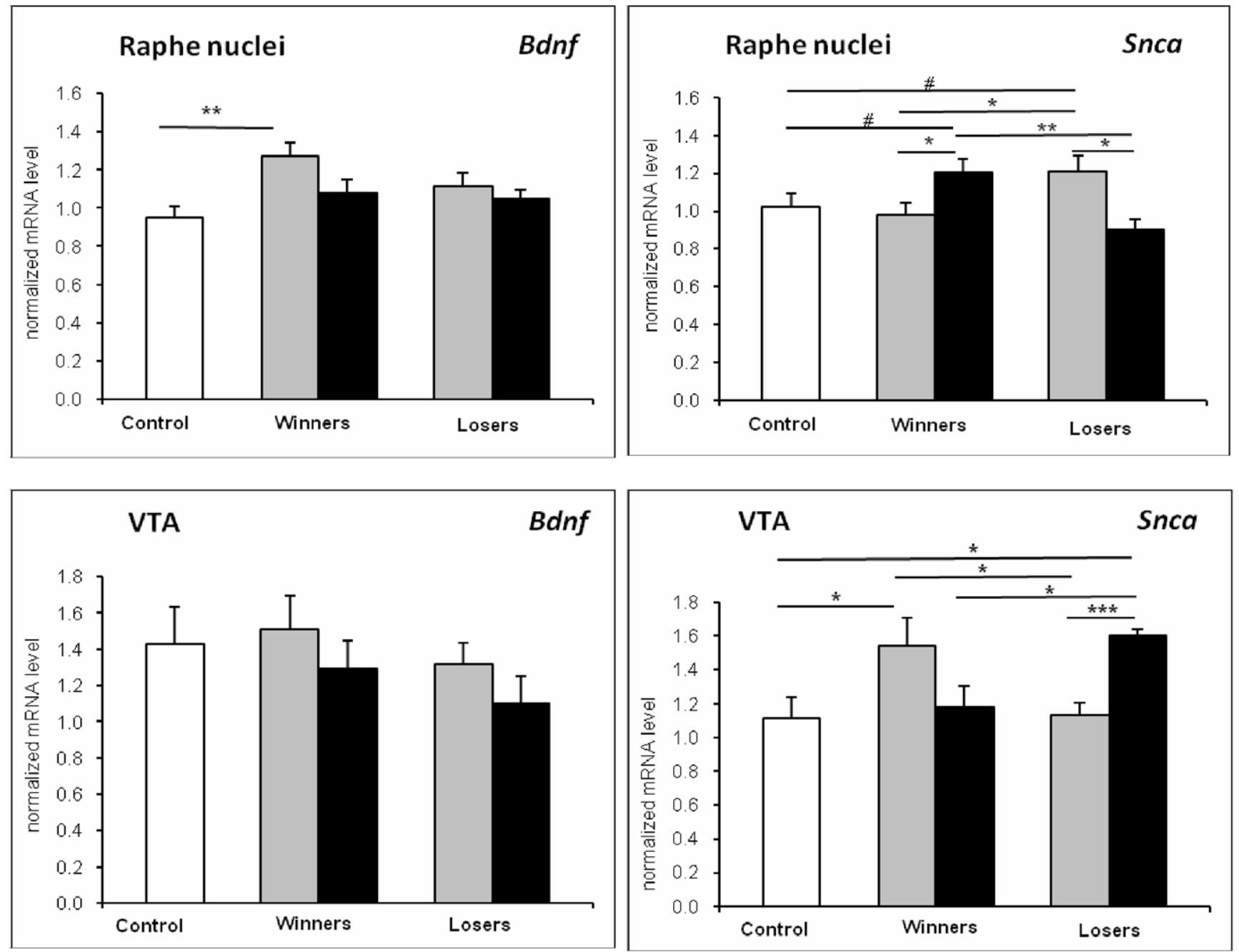

Figure 1. The normalized Snca and Bdnf mRNA levels in the VTA and raphe nuclei of midbrain of the controls (white columns), 20time winners and 20-time losers (grey columns) and no-fighting winners and no-fighting losers (black columns). ${ }^{*} p<0.05 ;{ }^{* *} p<0.01$; *** $p<0.001 ; \#-0.05<p<0.1$ comparisons between respective groups. doi:10.1371/journal.pone.0014089.g001

losers' raphe nuclei shown earlier [12,13,18]. After no-fight period mRNA level of Snca gene reverts to the control level. Noteworthy, over-expression of the Snca gene in the VTA was found in the 20time winners and in the no-fighting losers in comparison with the control. Some authors suggest [6] that over-expression of the Snca gene may block its neuroprotective properties. Our observations are in agreement with those of Mash and co-workers [34] who have demonstrated over-expression of Snca gene in the VTA in chronic cocaine abusers, which was shown to activate the brain dopaminergic systems [35]. Increased mRNA level of Snca gene was also found after amphetamine injections [36].

Two-way ANOVA for Bdnf mRNA levels did not reveal significant interaction effects for "social status" and "no-fight period" in both areas. However, the expression of some genes may increase rapidly and decrease abruptly, while that of other genes changes more gradually [37]. As Miczek and the co-workers report [38], continuous subordination stress leads to significantly decreased levels of BDNF protein in the VTA compared to control levels, whereas intermittent social defeat stress episodes result in increased BDNF protein levels. Thus, the lack of changes in $B d n f$ mRNA levels in the 20-time losers could be explained by transient (dynamic) changes of gene expression shown, for example, for the genes of kappa-opioid receptors [39,40], muopioid receptors [41,42], and proenkephalin [43] in some brain areas in response to exposure to the experimental settings. If this explanation is correct, we cannot completely exclude the involvement of $B d n f$ in the mechanisms underlying repeated aggression or defeats. This expectation is supported by increased Bdnf mRNA level in the 20-time winners' raphe nuclei in comparison with the controls and by the presence of positive functional correlations between the Bdnf and Snca mRNA levels in the raphe nuclei. These data suggest that BDNF may play an important role in regulation of serotonergic activity. In the VTA, positive correlation between the Bdnf and Snca mRNA levels was found only in the control mice. However, the intrinsic molecular mechanisms responsible for the functional association have yet to be revealed. The reason for this correlative relationship might be the common molecular mechanisms of transcriptional regulation of these genes.

Thus, chronic manifestation of aggression, which leads to activation of dopaminergic metabolism in the brain areas, enhances in the VTA the expression of the Th, Dat1 and Snca 
genes [13], whose proteins are responsible for the DA functioning. Mesolimbic dopaminergic projections from the VTA play an important role in the mediation of rewarding processes. It is therefore possible that the observed changes of the Snca genes expression display the dopaminergic mechanisms from experiencing positive emotions over social victories in the winners. Because social defeats lead to the activation of the serotonergic system $[17,44]$, the changes in the Snca mRNA levels in the losers' raphe nuclei lend support to the involvement of a-Syn in the consequence of chronic negative emotions.

It has been shown earlier that long positive fighting history leads to development of behavioral psychopathology, which includes the demonstration of abnormal aggression, malignancy, strong hostility, pronounced anxiety, disturbances in social recognition, hyperactivity, stereotypic and hyperkinetic reactions [16]. Male mice with long defeat history developed a psychoemotional disorder similar to anxious depression in accordance with symptomatics, etiology factors, brain neurochemical changes and sensitivity to antidepressants and anxiolytics similar to those in depressive persons $[17,44]$. It may be concluded that Snca gene may be involved in pathogenesis of these disorders. In this context

\section{References}

1. George JM (2002) The synucleins. Genome Biol 3(1): REVIEWS3002.

2. Totterdell S, Hanger D, Meredith GE (2004) The ultrastructural distribution of alpha-synuclein-like protein in normal mouse brain. Brain Res 1004(1-2): 61-72.

3. Wersinger C, Rusnak M, Sidhu A (2006) Modulation of the trafficking of the human serotonin transporter by human alpha-synuclein. Eur J Neurosci 24(1): $55-64$.

4. Wersinger C, Jeannotte A, Sidhu A (2006) Attenuation of the norepinephrine transporter activity and trafficking via interactions with alpha-synuclein. Eur J Neurosci 24(11): 3141-3152.

5. Yavich L, Tanila H, Vepsalainen S, Jakala P (2004) Role of alpha-synuclein in presynaptic dopamine recruitment. J Neurosci 24: 11165-11170.

6. Sidhu A, Wersinger C, Moussa CE, Vernier P (2004) The role of alphasynuclein in both neuroprotection and neurodegeneration. Ann NY Acad Sci 1035: 250-270.

7. Kao AW, Racine CA, Quitania LC, Kramer JH, Christine CW, et al. (2009) Cognitive and neuropsychiatric profile of the synucleinopathies: Parkinson disease, dementia with lewy bodies, and multiple system atrophy. Alzheimer Dis Assoc Disord 23(4): 365-370.

8. Frieling H, Gozner A, Römer KD, Wilhelm J, Hillemacher T, et al. (2008) Alpha-synuclein mRNA levels correspond to beck depression inventory scores in females with eating disorders. Neuropsychobiology 58(1): 48-52.

9. Jeannotte AM, McCarthy JG, Redei EE, Sidhu A (2009) Desipramine modulation of alpha-, gamma-synuclein, and the norepinephrine transporter in an animal model of depression. Neuropsychopharmacology 34(4): 987-998.

10. Kudriavtseva NN, Bakshtanovskaia IV (1991) The neurochemical control of aggression and submission. Zh Vyssh Nerv Deiat Im IP Pavlova 41: 459-466.

11. Devoino LV, Idova GV, Al'perina EL, Cheido MA (1998) The neurochemical set of the brain-an extra-immune mechanism of psychoneuroimmunomodulation. Vestn Ross Akad Med Nauk 9: 19-24.

12. Filipenko ML, Alekseyenko OV, Beilina AG, Kamynina TP, Kudryavtseva NN (2001) Increase of tyrosine hydroxylase and dopamine transporter mRNA levels in ventral tegmental area of male mice under influence of repeated aggression experience. Brain Res Mol Brain Res 96: 77-81.

13. Bondar NP, Boyarskikh UA, Kovalenko IL, Filipenko ML, Kudryavtseva NN (2009) Molecular implications of repeated aggression: Th, Dat1, Snca and Bdnf gene expression in the VTA of victorious male mice. PLoS ONE 4(1): e4190.

14. Amstislavskaya TG, Kudryavtseva NN (1997) Effect of repeated experience of victory and defeat in daily agonistic confrontations on brain tryptophan hydroxylase activity. FEBS Lett 406: 106-108.

15. Kulikov AV, Kozlachkova EY, Kudryavtseva NN, Popova NK (1995) Correlation between tryptophan hydroxylase activity in the brain and predisposition to pinch-induced catalepsy in mice. Pharmacol Biochem Behav 50:3: 431-435.

16. Kudryavtseva NN (2006) Psychopathology of repeated aggression: a neurobiological aspect. In Morgan JP, ed. Perspectives on the Psychology of Aggression NOVA Science Publishers Inc. pp 35-64.

17. Avgustinovich DF, Alekseyenko OV, Bakshtanovskaya IV, Koryakina LA, Lipina TV, et al. (2004) Dynamic changes of brain serotonergic and dopaminergic activities during development of anxious depression: Experimental Study. Usp Fiziol Nauk 35(4), 19-40. Russian.

18. Filipenko ML, Beilina AG, Alekseyenko OV, Dolgov VV, Kudryavtseva NN (2002) Increase in expression of brain serotonin transporter and monoamine our assumption is in agreement with earlier reports $[8,45,46]$ which have demonstrated that the ability of $\alpha$-Syn to modulate SERT and DAT functions may be of pathological significance, particularly with regard to psychiatric disorders such as depression, suicide, and impulsive violence.

It must be noted that the activities of all neurotransmitter systems may be dynamically changed as for metabolism, receptors and enzyme activities in male mice in response to chronic activation or inhibition of neurotransmitter' systems depending on social status and/or duration of repeated agonistic interactions $[16,17]$. Our behavioral approach makes it possible to track changes in gene functioning during development of behavioral pathologies [47], and to study the transcriptional state of a set of genes, which may be involved in the brain pathogenesis.

\section{Author Contributions}

Conceived and designed the experiments: NNK. Performed the experiments: NNB UAB MLF. Analyzed the data: NNK NNB UAB MLF. Contributed reagents/materials/analysis tools: UAB MLF. Wrote the paper: NNK NNB MLF.

oxidase a genes induced by repeated experience of social defeats in male mice. Biochemistry 67: 451-455.

19. Cooper SJ (1991) Interaction between endogenous opioids and dopamine: Implications for reward and aversion. In: Willner P\& Scheel-Kruger J, eds. The mesolimbic dopamine system: from motivation to action. London: John Wiley Sons Ltd. pp 331-366.

20. Fish EW, De Bold JF, Miczek KA (2002) Aggressive behavior as a reinforcer in mice: activation by allopregnanolone. Psychopharmacology (Berl) 163: 45966.

21. Scott JP. Theoretical issues concerning the origin and causes of fighting. In: EBEaS JP, ed. The physiology of aggression and defeat. New-York: Plenum Press; 1971, 11-42.

22. Groves JO (2007) Is it time to reassess the BDNF hypothesis of depression? Mol Psychiatry 12: 1079-1088.

23. Greenberg ME, Xu B, Lu B, Hempstead BL (2009) New insights in the biology of BDNF synthesis and release: implications in CNS function. J Neurosci 29(41): 12764-12767.

24. Parain K, Murer MG, Yan Q Faucheux B, Agid Y, et al. (1999) Reduced expression of brain-derived neurotrophic factor protein in Parkinson's disease substantia nigra. Neuroreport 10: 557-561.

25. Yuan Y, Sun J, Zhao M, Hu J, Wang X, et al. (2010) Overexpression of alphasynuclein down-regulates BDNF expression. Cell Mol Neurobiol Apr 20. [in press].

26. Kudryavtseva NN (1991) The sensory contact model for the study of aggressive and submissive behaviors in male mice. Aggress Behav 17: 285-291.

27. Avgustinovich DF, Kovalenko IL, Bondar NP (2005) Choice of "control" in experimental researches of animal social interactions in mice. Ross Fiziol Zh Im I M Sechenova 91(12): 1454-68. Russian.

28. Rosen GD, Williams AG, Capra JA, Connolly MT, Cruz B, et al. (2000) The Mouse Brain Library@www.mbl.org. Int. Mouse Genome Conference, 14, 166. www.mbl.org.

29. Chomczynski P, Sacchi N (1987) Single-step method of RNA isolation by acid guanidinium thiocyanate-phenol-chloroform extraction. Anal Biochem 162: $156-159$.

30. Coccaro EF (1992) Impulsive aggression and central serotonergic system function in humans: an example of a dementional brain behavior relationship. Int Clin Psychopharmacol 7: 3-12.

31. Miczek KA, Faccidomo SP, Fish EW, DeBold JF (2007) Neurochemistry and molecular neurobiology of aggressive behavior In Lajtha A, Blaustein JD, eds. Handbook of Neurochemistry and Molecular Neurobiology: Behavioral neurochemistry, neuroendocrinology and molecular neurobiology. SpringerVerlag, Berlin, Heidelberg. pp 285-336.

32. de Boer SF, Caramaschi D, Natarajan D, Koolhaas JM (2009) The vicious cycle towards violence: focus on the negative feedback mechanisms of brain serotonin neurotransmission. Front Behav Neurosci 3: 52.

33. Wersinger C, Sidhu A (2003) Attenuation of dopamine transporter activity by alpha-synuclein. Neurosci Lett 340: 189-192.

34. Mash DC, Ouyang O, Pablo J, Basile M, Izenwasser S, et al. (2003) Cocaine abusers have an overexpression of alpha-synuclein in dopamine neurons. J Neurosci 23(7): 2564-2571.

35. Kreek MJ (1996) Cocaine, dopamine and the endogenous opioid system. J Addict Dis 15(4): 73-96. 
36. Mauceli G, Busceti CI, Pellegrini A, Soldani P, Lenzi P, et al. (2006) Overexpression of alpha-synuclein following methamphetamine: is it good or bad? Ann NY Acad Sci 1074: 191-197.

37. Nichols CD, Garcia EE, Sanders-Bush E (2003) Dynamic changes in prefrontal cortex gene expression following lysergic acid diethylamide administration. Brain Res Mol Brain Res 111: 182-188.

38. Miczek KA, Yap JJ, Covington HE, III (2008) Social stress, therapeutics and drug abuse: Preclinical models of escalated and depressed intake Pharmacol Therap 120(2): 102-128.

39. Goloshchapov AV, Filipenko ML, Bondar NP, Kudryavtseva NN (2005) Decrease of kappa-opioid receptor mRNA level in ventral tegmental area of male mice after repeated experience of aggression. Brain Res Mol Brain Res 135: 290-292.

40. Spangler R, Ho A, Zhou Y, Maggos CE, Yuferov V, et al. (1996) Regulation of kappa opioid receptor mRNA in the rat brain by "binge' pattern cocaine administration and correlation with preprodynorphin mRNA. Brain Res Mol Brain Res 38: 71-76.

41. Azaryan AV, Clock BJ, Rosenberger JG, Cox BM (1998) Transient upregulation of $\mathrm{mu}$ opioid receptor mRNA levels in nucleus accumbens during chronic cocaine administration. Can J Physiol Pharmacol 76: 278-283.
42. Nikulina EM, Hammer RP, Jr., Miczek KA, Kream RM (1999) Social defeat stress increases expression of mu-opioid receptor mRNA in rat ventral tegmental area. Neuroreport 10: 3015-3019.

43. Crespo JA, Manzanares J, Oliva JM, Corchero J, Palomo T, et al. (2001) Extinction of cocaine self-administration produces a differential time-related regulation of proenkephalin gene expression in rat brain. Neuropsychopharmacology 25: 185-194.

44. Kudryavtseva NN, Avgustinovich DF (1998) Behavioral and physiological markers of experimental depression induced by social conflicts (DISC). Aggress Behav 24: 271-286.

45. Hahn MK, Blakely RD (2002) Monoamine transporter gene structure and polymorphisms in relation to psychiatric and other complex disorders. Pharmacogenomics J 25: 487-495.

46. Heinz A, Mann K, Weinberger DR, Goldman D (2001) Serotonergic dysfunction, negative mood states, and response to alcohol. Alcohol Clin Exp Res 25: 487-495.

47. Kudriavtseva NN, Filipenko ML, Bakshtanovskaia IV, Avgustinovich DF, Alekseenko OV, et al. (2004) Changes in the expression of monoaminergic genes under the influence of repeated experience of agonistic interactions: from behavior to gene. Russ J Genetics 40: 590-604. 